

\title{
Ecumenical foundations? On the coexistence of Austrian and neoclassical views on utility
}

Senderski, Marcin

Kozminski University

2014

Online at https://mpra.ub.uni-muenchen.de/67024/

MPRA Paper No. 67024, posted 04 Oct 2015 06:20 UTC 


\section{Ecumenical foundations? On the coexistence of Austrian and neoclassical views on utility}

\section{Note on terminology}

Although it is sensible to refer to the Austrian school and the Austrian economists with a small rather than a capital letter (as it denotes the affiliation to a particular current, not the nationality), the prevailing consensus is to apply capital "A" with "Austrian", regardless of its actual usage. The author respects this consensus, even though he does not agree with it. 


\begin{abstract}
Utility has always been a debatable concept, with many competing interpretations. The Austrian school and the neoclassical school, however broad these categories may seem, have made the most substantial and, by the same token, the most contrasting contributions to the theory of value. The paper's goal is not to adjudicate past arguments or observe the evolution of the theory, but rather to resolve contemporary misunderstandings. The references are made to such trouble spots as subjectivism vs. objectivism, cardinality vs. ordinality, and mathematical formalism vs. verbal formalism. Both schools entrenched themselves in their views long ago. Nevertheless, this paper shows that discussing utility on common ground and on the basis of shared presumptions is not necessarily the melody of the future. The paper is concluded with recommendations on how the current dissent may be attenuated.
\end{abstract}

Keywords: Utility, Austrian school, neoclassical school, heterodox economics, economic thought

JEL Classification: B41, B53 


\section{Introduction}

The dissent prevails between the major schools active in the economic debate. The logic presented by them is rarely tangent and the recommendations contradict each other. On the one hand, disagreements may be stimulating and it should be seen as opportunity when one school challenges another. On the other hand, however, their obstructive nature is hard to overlook. The antagonism between the well-established neoclassical school and the reviving Austrian school is profound, stemming from their different views on the world, reality and the status of economics as a science. At the same time, some conflicts that comprise this friction seem over-sophisticated, flowing from the ill will or too inflexible interpretation of opponent's definitions, rather than from genuine opposition. Notwithstanding that the tensions between neoclassical and Austrian economists have been tried to be appeased several times, a considerable deal of discord and suspicion continues. Articles have also been published on how to effectively communicate between schools, among others Vernengo (2010) and Colander et al. (2010), both from post-Keynesian perspective. Within the same stream, Setterfield (2009) has tried to reconcile neoclassical growth theory with heterodox growth theory. Interestingly, he observed that the obstacles to interschool interaction are associated with 'methodology, rhetoric and the sociology of the economics profession' (Setterfield 2009, 21). It would not be far from the truth to say that the dissensions present in the Austrian-neoclassical dialogue may be well attributed to the same obstacles. Although sharp distinctions never hold and also in this case many economists would oppose to be pigeonholed as neoclassical or Austrian, it is certainly possible to write about two currents of economics thinking. Both schools are full of internal incongruences, but those who argue that it is now unwise or impolitic to distinguish between a neoclassical and an Austrian are clearly wrong. Whereas there is a number of economists whose work is only remotely connected to the concept of utility - and they may oftentimes be defined as ideologically indifferent - the rest would rather eagerly opt for one or the other view on economic reality.

Utility, i.e. the value or importance that people attach to things, seems to be a construct on which the rapprochement may be obtained, unlike on the omnipresent narrative of economic equilibrium or on strong ties with mathematics, which the Austrian school consequently despises. The resolution of even less fundamental conflict zones, like indifference analysis, continuous preferences or welfare economics (Caplan 1999, 824), seems beyond reach. Yet, it is wise to start with utility, as this is still essential, though not so widely debated term in this day and age. The extent to which utility applies is broad - it is 
"roughly synonymous with satisfaction, well-being, welfare, happiness, pleasure, etc." (Kapteyn 1985, 1). And there were also currents that agreed to see utility as a "primitive term", which would imply no exact definition necessary. The goal of the paper is not to replicate the underlying theorems, but to indicate that the utility, when interpreted in a conciliatory spirit, may incorporate the premises and the rigor promoted by both currents.

The paper seems to be a viable contribution to both economic theory and economic practice. First, the utility constitutes a central construct of economic thinking and the intellectual unification will facilitate the transferability of knowledge, thus possibly opening up untapped research areas. Second, as the hatchet will be half-way buried, a milestone would be marked in the relationship between the two schools. The concept of utility is taught on the first year on economic faculties all over the world, and students can recite by heart the definition of it. Reaching convergence on its interpretation will reinforce confidence in utility as a fundamental strength of the economic way of thinking, irrespective of the espoused perception.

Utility has become the central concept in economic sciences long time ago and remains in good standing. It is important to both schools, although the history of its evolution was different. On the one hand, the Austrian economics never elaborated a comprehensive theory of welfare economics. Instead, the Austrians were concentrated on developing their value theory (Myrdal 1954, 128). During his interview with Axel Leijonhufvud, Hayek candidly revealed: "it was the marginal utility analysis which to us was the Austrian school" (Foundation for Research in Economics and Education 1978). However, marginal approach to value was developed independently in the 1870 s by Carl Menger in Austria, William Stanley Jevons in the United Kingdom and Léon Walras in Switzerland (Stigler 1950b, 315316). It superseded the then prevailing and yet obsolete labor theories of value, of various origin (Ricardian, Smithian, Marxian), arguing the value of a commodity is only related to the labor needed to produce or obtain that commodity. Nonetheless, it took some time for it to happen, as the initial academic response to the new "heresy" was rather cold (Drakopoulos and Karayiannis 1999, 68-70). In spite of the fact that only one out of three architects of what was later called "marginalist revolution" (Carl Menger) belonged to the founders of Austrian school, it was not before the 1930s when the Austrians were started to be labeled "heterodox". Before that happened, the utility theory was discussed within the mainstream, and not between the mainstream and the periphery of economic sciences. All in all, the concept of utility has never been defining and decisive for neoclassical doctrine to an extent to which it was formative for the Austrian tradition. 


\section{The definitions of schools}

No attempt to reconcile Austrian and neoclassical views on utility may succeed unless both currents are clearly defined. This is delicate matter, though, as economic schools are not usually led by popes granting imprimaturs to papers published by their representatives, and what is published by one of school's researchers is not automatically welcomed as a dogma by her colleagues.

First, what is meant by "the Austrian school"? As is well known, the Austrian school has evolved from the founders over successive generations until the beginning of World War II when many of its members emigrated, mostly to the United States and transformed into what has been called the "neo-Austrians". The views expressed by Menger, Murray Rothbard or Ludwig von Mises were certainly not alike. There was (and there is) no homogenous and unchanging view of utility among economists of Austrian denomination. Indeed, there has been an intense debate on concepts of utility among Austrians in the interwar period, and members of the school like Friedrich Hayek, Gottfried Haberler, Felix Kaufmann, Hans Mayer and Mises favored quite distinct approaches (see e.g. Rosenstein-Rodan 1960; Sweezy 1934). Also within more contemporary Austrian currents the tensions prevail, e.g. between Israel Kirzner and Rothbard (Mahoney 2011), or - more fundamentally - between Mises and Hayek, the so-called "dehomogenization" (Salerno 2002). Whenever the reference is made to the Austrian school here, the focus is on its contemporary properties. This is rational given that the "old" Austrians, unlike their intellectual offspring, typically had their say in the mainstream and enjoyed factual power to shape the mainstream theories.

Now, what is meant by "neoclassical"? This is a term which can be legitimately used for various purposes. It may be used historically, to designate the system of thought that evolved after 1870 in Cambridge, Lausanne and also Vienna, as Carl Menger is sometimes included on the lists of neoclassical economists (see Colander 2000). This system became the basis of modern microeconomics. Or, it might be used, as has often been done by critics, as a label for the mainstream of economics after 1945 characterized by the concepts of equilibrium and utility maximization. Indeed, the notion is frequently used as an allencompassing and unhistorical category that includes everyone who is not Marxist or heterodox.

The term "neoclassical" was first used by Thorstein Veblen in 1900 (Aspromourgos 1986), but hardly gained prominence in the economic literature until the 1950s. Yet in 1898 
Veblen drafted the differences between three "schools of economic thought that were historically subsequent to the classical and Marxian schools": neoclassical, then named "later classical" or "recent classical" (Alfred Marshall and John Bates Clark), Austrian (BöhmBawerk and Menger) and German historical school (Gustav Schmoller) (Hodgson 1998, 424). There, both of the first two schools were heavily criticized for their hedonistic assumptions, depicting a human being as a "lightning calculator", which could possibly be interpreted as a criticism of utility maximization behavior per se (Veblen 1898, 389-390).

Arnsperger and Varoufakis (2006) list the three axioms of the neoclassical school: methodological individualism, methodological instrumentalism and methodological equilibration, and say that despite its never-ending metamorphoses, the neoclassical school remains faithful to these three basics. In general, neoclassical economists tend to portray the economic agent as homo oeconomicus, being independent, utility-maximizing, having rational preferences and the access to perfect information. Certainly, these economists do not perceive utility in the same way, but a set of assumptions is more or less common. Therefore, whenever the reference is made to neoclassical economists, these will be scholars that avowedly espouse these suppositions.

Many neoclassical economists have developed quite thorough and in-depth views on utility, hence it is not feasible to replicate them here in short. Below are some extracts from various classical and neoclassical economists, which testify to the diversity of their perceptions.

Table 1. Key remarks on leading classical and neoclassical economists' perceptions of utility

\begin{tabular}{|l|l|}
\hline Jeremy Bentham (2000 & $\begin{array}{l}\text { As he himself expressed it, "planted the tree of utility". } \\
\text { Attempted to be holistic in his philosophy of omnipresent } \\
\text { utilitarianism. Positive about measurements and utility } \\
\text { aggregation, although aware of the underlying technical } \\
\text { problems. Associated utility with wealth. In fact, encountered } \\
\text { problems and traps typical for trendsetters. }\end{array}$ \\
\hline $\begin{array}{l}\text { Francis Ysidro Edgeworth } \\
(1879 ; 1881)\end{array}$ & $\begin{array}{l}\text { Created indifference curves and dreamt of hedonimeter. } \\
\text { Devoted Benthamite, but - as Jürg Niehans (1989, 282) put it - } \\
\text { "by an irony of history (...) became the pathfinder of } \\
\text { ordinalism". }\end{array}$ \\
\hline $\begin{array}{l}\text { William Stanley Jevons } \\
(1888)\end{array}$ & $\begin{array}{l}\text { Saw economy as a calculus of pleasure and pain. Although did } \\
\text { not believe in direct measurement of utility and did not really } \\
\text { support either cardinal or ordinal utility, his advanced } \\
\text { mathematics heavily relied upon cardinal utility functions. }\end{array}$ \\
\hline Léon Walras (Walras & Father of (diminishing) marginal utility, built upon his father's \\
\hline
\end{tabular}




\begin{tabular}{|c|c|}
\hline $1954[1874])$ & $\begin{array}{l}\text { concept of rareté (scarcity). Uneasy about measurements. } \\
\text { Scarcity was later incorporated by both Austrian and } \\
\text { neoclassical economists, also within the utility theory (see } \\
\text { Bonar 1888, 11; Matthaei 1984; Langlois 1985; Rothbard 1995, } \\
\text { 26; Daoud 2011). }\end{array}$ \\
\hline Alfred Marshall (1920) & $\begin{array}{l}\text { Relatively similar to Jevons. Distinguished desires from the } \\
\text { realized satisfactions. Admitted the impossibility of } \\
\text { measurement, at least contemporarily. }\end{array}$ \\
\hline $\begin{array}{l}\text { Vilfredo Pareto (1971 } \\
\text { [1906]) }\end{array}$ & $\begin{array}{l}\text { One of the fathers of ordinality, marked the full rejection of } \\
\text { Benthamite utilitarianism and cardinality, demonstrated the } \\
\text { immeasurability of utility. Built on Edgeworth's indifference } \\
\text { curves and as such facilitated the emergence of revealed } \\
\text { preference theory. }\end{array}$ \\
\hline $\begin{array}{l}\text { John Richard Hicks } \\
\text { (1946), also with Roy } \\
\text { Allen (1934) }\end{array}$ & $\begin{array}{l}\text { Took off from admitting that utility is not measurable, and if } \\
\text { so, the notion of marginalism must be eliminated in } \\
\text { consequence. Developed robust theory of consumer behavior } \\
\text { under perfect competition and certainty and thus reinforced } \\
\text { ordinalism. }\end{array}$ \\
\hline $\begin{array}{l}\text { Paul Anthony Samuelson } \\
(1937 ; 1938 ; 1948 ; 1950)\end{array}$ & $\begin{array}{l}\text { Pioneered the revealed preference approach and claimed it a } \\
\text { method to observe consumer's utility function (although } \\
\text { several scholars practically followed this approach before). } \\
\text { Eventually, demonstrated equivalence of revealed preference } \\
\text { and ordinal utility theory. }\end{array}$ \\
\hline Maurice Allais (1953) & $\begin{array}{l}\text { Found, through an experiment, inconsistency between revealed } \\
\text { preference and expected utility theory (later monikered the } \\
\text { Allais paradox). Developed, independent from von Neumann } \\
\text { and Morgenstern, a theory of cardinal utility, measured by } \\
\text { differences of levels of satisfaction. }\end{array}$ \\
\hline $\begin{array}{l}\text { Daniel Kahneman and } \\
\text { Amos Tversky (1979; } \\
\text { 1992), as well as } \\
\text { Kahnemann with Peter P. } \\
\text { Wakker and Rakesh Sarin } \\
(1997)\end{array}$ & $\begin{array}{l}\text { Differentiated decision utility (weight of an outcome in a } \\
\text { decision) and experienced utility (Benthamite hedonism), using } \\
\text { vital psychological elements (e.g. framing effect, reference } \\
\text { point, loss aversion). Were ambiguous about the utility } \\
\text { maximization standard. Incorporated probability theory into } \\
\text { utility studies. In a way, rehabilitated Bentham, as portrayed by } \\
\text { Read (2007, 46). }\end{array}$ \\
\hline $\begin{array}{l}\text { Faruk Gül and Wolfgang } \\
\text { Pesendorfer }(2006 ; 2013)\end{array}$ & $\begin{array}{l}\text { Studied utility with relation to uncertainty, randomness, } \\
\text { temptation and self-control. Specialized in the theory of } \\
\text { decision and choice. }\end{array}$ \\
\hline $\begin{array}{l}\text { Matthias Benz, Alois } \\
\text { Stutzer and Bruno S. Frey } \\
\text { (Benz and Stutzer 2003; } \\
\text { Benz 2005; Frey, Benz, } \\
\text { and Stutzer 2004; Frey } \\
\text { and Stutzer 2005a) }\end{array}$ & $\begin{array}{l}\text { Introduced the so-called "procedural utility", finding that } \\
\text { people do not only care about outcomes, but also about the } \\
\text { processes and conditions leading to outcomes. Based on the } \\
\text { example of the political decision-making process, where people } \\
\text { enjoy the very influence they may exert and not so much the } \\
\text { final outcome of their participation. The construct of procedural } \\
\text { utility does not seem to contradict in any sense neither } \\
\text { neoclassical nor Austrian paradigm. }\end{array}$ \\
\hline
\end{tabular}

Within the neoclassical tradition there is also discussion on utility's place, and in particular the interpersonal comparison of utility (Blaug 2007; Kaldor 1939; Pigou 1951; 
Hammond 1991) and growth models (Sidrauski 1967; Proops and Speck 1996) are the focal point. Moreover, the more sophisticated comparisons are pursued, e.g. utility in the context of social reference group (Kapteyn, van Praag, and van Herwaarden 1978).

\section{Literature survey and the dissent on utility}

Not being the founding myth of the neoclassical school, the concept of utility is still central to it, as it is involved in virtually all optimization problems. On the contrary, the Austrians claim since long that it was utility that helped them to emancipate. Simultaneously, they severely denounce utility in its neoclassical sense - relatively objective and quantifiable.

Utility has always been a debatable concept, with many competing interpretations (Abdellaoui, Barrios, and Wakker 2007). But many theories developed by "first wave" Austrian economists have been later absorbed into most mainstream schools of economics.

These include Menger's theories on marginal utility or Friedrich von Wieser's introduction of opportunity cost, then called "sacrificed utility" (White 2003, 12). The logical corollary of marginal approach to utility was the final utility. In essence, when attaching the value to a unit of a commodity, man decides on the basis of the value of the least important use this commodity satisfies (Mises 1996, 123; E. v. Böhm-Bawerk and Leonard 1891, 364; Davenport 1902, 361). The same line of reasoning was described much earlier by e.g. James Bonar (1888), insisting that final utility should be seen as the nature, and not the cause of value. Throughout the twentieth century, since many anomalies became apparent, the wellestablished paradigm of ordinal and observable utility, most well formulated by Rothbard (1956), has been seriously challenged (Salerno 2002, 116). The psychological literature has notably contributed to this evolution, with Tinbergen (1991), Kahneman (1994) or Loewenstein (2000) being the most influential.

\section{Objectivism vs. subjectivism and psychology}

One of the least fierce discussions prevails now in the field of objectivity or subjectivity of utility. The first is strongly rejected by Austrians, not only with regard to utility, but with regard to virtually any constituent of economic domain. However, most of neoclassical economists today seem to adopt this position, too, and would not maintain that utility is as an objective notion, as confirmed Stringham (2010, 63) who noted: "almost all economists can be classified as believing in some type of economic subjectivism, but many 
can only be classified as believing in economic subjectivism in the weakest sense". Still, some Austrian economists like to portray neoclassical economists, more or less directly, as holding an opposite view (Kirzner 1988, 11; Huerta de Soto 2008, 37-40).

As Menger, the father of subjectivist Austrian school once noted, "the value of goods arises from their relationship to our needs, and is not inherent in the goods themselves" (Menger 2007, 120). The allies in this matter are e.g. Nassau William Senior (1836), as well as even more "prehistoric" John Stuart Mill (1909), perhaps capable of uniting economists of all denominations, who wrote:

If one thing, either by itself or by what it would purchase, could maintain a laboring man for a day, and another could maintain him for a week, there would be some reason in saying, that the one was worth, for ordinary human uses, seven times as much as the other. But this would not measure the worth of the thing to its possessor for his own purposes, which might be greater to any amount, though it could not be less, than the worth of the food which the thing would purchase.

Also, as Seligman (1903, 360-361) wrote on William Forster Lloyd's theory, the utility "is predicated of an object with reference to the wants of mankind. Ice is useful in summer, useless in winter. Still the intrinsic qualities of ice are at all times and in all places the same". In fact, the one who seeks academic literature in favor of subjective notions of utility, has rich selection. Marshall, notwithstanding his invaluable (at least for some) contribution to expand the mathematical rigor of economics, had quite lax views on utility: it "is taken to be correlative to Desire or Want" and these "cannot be measured directly" (1920, 61). Marshall also believed in measuring utility at the margin $(1920,15)$ :

For instance the pleasures which two persons derive from smoking cannot be directly compared: nor can even those which the same person derives from it at different times. But if we find a man in doubt whether to spend a few pence on a cigar, or a cup of tea, or on riding home instead of walking home, then we may follow ordinary usage, and say that he expects from them equal pleasures.

If then we wish to compare even physical gratifications, we must do it not directly, but indirectly by the incentives which they afford to action. If the desires to secure either of two pleasures will induce people in similar circumstances each to do just an hour's extra work, or will induce men in the same rank of life and with the same means each to pay a shilling for it; we then may say that those pleasures are equal for our purposes, because the desires for them are equally strong incentives to action for persons under similar conditions.

Edwin Cannan, Marshall's adherent, disregarded utility as the synonym of usefulness, and proposed Pareto's ophelimity or its English counterpart, desiredness, as substitutes. 
However, contrary to popular beliefs, ophelimity has narrower base than conventional utility, as it is purely economic, in Pareto's view, and does not include ethical, moral, religious, and political components (Tarascio 1969, 7). Even more skillfully than the others, Cannan referred to the Prayer Book, which contains both "a prayer for the cessation of rain as well as one for rain", to underline the mistake of regarding utility as something inherent in things rather than something rooted in human minds or circumstances $(1964,197)$. As for now, Kahneman (1999; 2006 with Krueger) seems to be the only major economist stuck in between objectivism and subjectivism.

Subjectivism is the essence of Austrian economics (Block 1999, 23-25; O'Driscoll and Rizzo 1985, 22), although the impressive summary by Diener et al. (1999) indicates that subjective well-being is a topical research issue in the mainstream, at least among psychology-driven economists. For instance, Frey and Stutzer (2002; 2005b) elaborated several papers devoted to the interrelations between utility and happiness, trying to incorporate happiness research into economics, but they failed to make any reference to the legacy of Austrian theorists in the realm of subjectivist approach to utility. But the revival of psychological and behaviorist inclinations within the neoclassical current bodes well for the future. Austrian version of utility exhibits solid psychological component. This intangible, psychological dimension was, until recently, almost inexistent in the neoclassical economics, which was purified throughout the 20th century from virtually all discussions run on psychological aspects of rational behaviors. Nevertheless, the Austrian school also rejects psychology in a sense of explaining human actions - they are rather concentrated on revealed actions themselves, ignoring the whole thought mechanisms that lead humans to undertake this or another action (Rajsic 2009). As Langlois $(1985,19)$ recalled, Mises succeeded in his "quest to rid utility theory of psychology", and Rothbard (Rothbard 1997, 72) further reinforced this viewpoint. And this was not that obvious, as several Austrians, notably Leo Schönfeld-Illy, Mayer and Rosenstein-Rodan, stressed the deliberateness of economic choices and "continued the Wieserian tradition and attempted to retain psychology as the basis of economic theory" (White 2003, 13). Also, Bonar's (1888, 24-25) goal was not to let to convert economic discussion into psychological one, and criticized Böhm-Bawerk for failing to respect this demarcation. Nevertheless, first, Bonar himself was not an Austrian economist and second, the Austrian economics has developed since when he wrote his referenced paper. Indeed, one of the supporters of the Austrian School, as recognized by Hennipman (1987, 159), Lionel Robbins (1935, 88), emphasized quite emphatically the need to forsake the underestimation of psychology: "even if we restrict the object of Economics to 
the explanation of such observable things as prices, we shall find that in fact it is impossible to explain them unless we invoke elements of a subjective or psychological nature".

To sum up with a concluding remark on utility's inherent subjectivity and relativism, an example of Ève Curie Labouisse might be instructive. Although her life was an unstoppable passage of admirable achievements and good works, she herself felt as if she had brought shame on her family. As her mother (Maria Skłodowska-Curie) received two Nobel Prizes, her father (Pierre Curie) was granted one, so her sister (Irène Joliot-Curie), brother-inlaw (Frédéric Joliot-Curie) and husband (Henry Richardson Labouisse, Jr.), she had the right to feel empty-handed and deeply underrated. Although emphasizing this fact stemmed probably from nothing else than a decent sense of humor, it already gives food for thought. Similarly, aggregating individual welfare functions to create a community welfare function, what some neoclassical economists try from time to time, is deemed unfeasible by e.g. Amartya Sen (1985), who calls for replacing utility for capability. He demonstrates his point with the example of a jolly cripple with a very low aspiration level and the snobbish millionaire, deriving similar satisfaction only from champagne and caviar. The comparison of their utilities will be futile, unless one considers and compares their capabilities (Meeks 1984, 70-72).

\section{Measurability, cardinalism vs. ordinalism}

The temperature of discussions on utility's numerical representation was high from the very cradle, provided that Jean-Baptiste Say replied to Ricardo's "Principles", "an invariable measure of value is a pure chimera", as Rothbard $(1995,19)$ recalls. This also shows that the drift towards quantitative formalizations is not the invention of modern scholars. Bentham, the father of utilitarianism (the concept obviously linked to the utility theory, but unfeasible to be thoroughly discussed in this paper), argued that all human desires, even ridiculously diverse, may be reduced to a numerical representation and compared on quantitative basis. Pigou $(1951,301)$ wrote that comparisons of utility are justified "upon broad grounds of experience, reflection and conversation", without providing explicit proofs whatsoever. Interestingly, this has not deterred him from claiming in the same paper that individual's economic welfare is a state of mind or consciousness $(1951,288)$. Renn $(1998,55)$ says, in a neoclassical manner, that "the objective yardstick for measuring utility in economics is the amount of money somebody is willing to pay for a change that provides a higher degree of utility than remaining at the status quo". However, this would be too extreme for most 
contemporary neoclassical economists. Beginning with Walras (1954 [1874]) most of them, i.e. Phelps Brown (1934a), discarded willingness to pay as a measure of utility, as the former depends on factors independent of utility such as wealth.

As Rothbard $(1995,58)$ noted, the assumption of measurability turned out to be appealing "to the scientistic passion among economists". "All vague notions of happiness and desire, for Bentham, could be reduced to quantities of pleasure and pain", Rothbard concludes. Indirectly, Benthamite ideology lay grounds for further development of neoclassical economics, as it opened the door for government intervention and thus the welfare component on the neoclassical agenda (Rothbard 1995, 62). As Eabrasu $(2008,8)$ holds, the feature of cardinality is sustained quite artificially, as otherwise it would be difficult to study risk and uncertainty, as well as to develop welfare economics. The Austrians, who remained critical of Bentham, were generally not tempted by pursuing such an extension of the utility theory. Oddly enough, the notable representative of the Austrian school, Eugen Böhm von Bawerk (1890) defended the idea that utility is a quantitative and measurable notion. The only workable justification of his stance is perhaps that the ordinal utility came into existence as a formal concept yet after Böhm-Bawerk's treatise was published and back then any form of measurability implied measurability on a cardinal scale. Also, the core of Austrian economists nowadays tend not to follow Böhm-Bawerk in this respect. Some would claim cardinality with reference to some passages found in Menger's "Principles of Economics", but yet in the introduction to 1976 edition, Friedrich Hayek $(2007,19)$ rightly explains that although Menger occasionally raises the issue of measurability, his exposition makes it clear that by this he means only the relative, and not the absolute, importance of the wants. Therefore, we cannot speak of any Menger's adherence to the concept of cardinality.

Nevertheless, the problem with cardinality, generally rejected by Austrians, is more fundamental. As Hicks (1946, 19-20) argued, if Austrians reject quantitative premises and cardinality, a victim of this "must be the principle of Diminishing Marginal Utility", being therefore deprived of any exact sense. Indeed, ordinal measurement may not suffice to determine the properties of marginal utility, although the Austrian school continued to look for methods of circumventing this weakness. As it is demonstrated throughout McCulloch (1977), the Austrian approach is quantifiable and invulnerable to monotonic transformations of the utility function, which is instructive as the uniqueness up to positive linear transformation of the form $\alpha \mathrm{U}(\mathrm{x})+\beta$ is considered a sine qua non building block of cardinal utility (Moscati 2013). 
As Mises (1996, 94-95) asserts, "one must not forget that the scale of values or wants manifests itself only in the reality of action", and "the only source from which our knowledge concerning these scales is derived is the observation of a man's actions". Quite the reverse, William Stanley Jevons not only saw utility as an objective construct, but also wanted to give it a measure ("units of pleasure") (Gordon 1996), which his peer inventors of marginalism, Walras and Menger, generally avoided (Stigler 1950b, 318). Walras, for instance, maintained that utility cannot be measured in practice, but - puzzlingly - can be quantifiable just as physical quantities are, e.g. temperature. Pareto, in effect, compared it to the distance between the stars and the earth, which could not be measured back then, but still existed in an objective sense (Marchionatti and Gambino 1997, 1333-1334). As Bruni and Guala (2001, 44) quote, Pareto held that "to recognize that a quantity exists and to measure it are two different things". Many believed that quantifying utility is necessary to explain consumer behavior, but Pareto finally rejected this supposition (Marchionatti and Gambino 1997, 13341335).

Fisher and Pareto were first to determine that an ordinal utility suffices to explain human behavior (Kapteyn 1985, 3). An ordinal utility is accurate in ranking particular bundles, but says nothing about the actual difference in pleasure delivered by these bundles (i.e. a cardinal scale). It is thus more a theory of choice, rather than a barometer of happiness. Now, the point of discord is that Austrian economists do not generally believe that one can go beyond ordinality and assume cardinality. However, here the line of conflict is blurred. Leading neoclassical economists were doubtful that utility is possible to be measured cardinally, including Arrow (1963), Hicks and Allen (1934), and of course Pareto (1971 [1906]), who is broadly believed to inaugurate the "ordinalist revolution" in 1906 (Moscati 2013). Furthermore, Myrdal and Robbins (Hicks 1954, 794), and Caplan (1997, 4; 1999, 827) take a similar stance and the latter convinces solemnly that neoclassical economists do not believe in cardinal utility and use numbers just to summarize ordinal rankings, not to advocate any meaningful inferences on by how many "utils" one bundle beats the other bundle.

The anti-cardinalist stance of Austrians is not unequivocal, too. A prominent member of the pre-World War II Austrian school Oskar Morgenstern wrote that not only utilities, but also utility differences are comparable (Morgenstern 1931, 13-14). This idea was also assumed by Rosenstein-Rodan from the Austrian school or Lionel Robbins from the neoclassical school (Moscati 2013). Morgenstern along with John von Neumann (1944) are also widely referenced as proving consistency of cardinal utility function, however their 
reasoning suffered from some serious limitations (Read 2007). Also, Kapteyn's (1985, 4-5) autopsy instructs that the concept of cardinality is problematic. Nevertheless, he believes that both directly and indirectly measured utility are closely related concepts and yield similar results. On another note, Cooter and Rappoport (1984, 511-512) suggest that ordinalism and non-comparability are not necessarily inseparable, and the one does not imply the other. However, such an approach is criticized by Hennipman $(1987,153)$.

\section{Utility functions}

The serious debate on the existence of utility function began with Oskar Lange's (1934) paper, quickly refuted by Henry Phelps Brown (1934b), and commented upon by other notable economists, mainly from the London School of Economics. Lange put forth two postulates that, in his view, enable the measurability. First, that individuals can only rank combinations of goods, and second, that they are also able to rank transitions from one combination to another. The discussion that followed was shown coherently in Moscati (2013) who has not cited any major Austrian economists active in this field.

Utility functions per se in are not in opposition to the Austrian school, but as Barnett (2003, 42-43) notices in his well substantiated critique, they are in fact always cardinal. The crux of his paper is the inference that "it is not an ordinal ranking that gives rise to cardinal numbers", but "the ordinal ranking arises from the assigned cardinal number", being effectively a by-product of this cardinal number (Barnett 2003, 48).

Similarly, in the debate between the schools, the difference between continuous and discontinuous utility functions is raised, as evidenced in Rothbard (1956), It is the use of discrete units of utility that enables Austrian economists to speak of diminishing marginal utility, while representing utility by continuous functions leads neoclassical economists to reject diminishing marginal utility. Furthermore, Rothbard $(1962,263)$ states that "utilities are not quantities, but ranks". This is equally fundamental criticism as that of Mises, insisting that values "are not susceptible to mental grasp by the application of cardinal numbers" (Mises 1996, 204), or that "action [i.e. revealed preference] does not measure utility or value; it chooses between alternatives" (Mises 1996, 122). Whereas Caplan $(1999,827)$ offers quite misty response to this critique, it is perhaps more useful to believe that measuring cardinal utility is theoretically possible, although it is probably not yet feasible in technical terms. To not make it sound futurological is difficult, but the truth is that methodological arsenal expands over time. This does not necessarily have to be the Edgeworth's hedonimeter, i.e. 
"ideally perfect instrument, a psychophysical machine, continually registering the height of pleasure experienced by an individual" (Colander 2007, 217). The arduous work of van Praag, quoted in Kapteyn (1985) is an example that attempts are made. One may always woe that asking interviewees of whether they are very happy or moderately happy with an item, as van Praag did, implies doubtful and highly subjectivist data set, but it is certainly a tolerable spot to take off from.

The same unsolved methodological problem concerns aggregation of individual utilities into a societal welfare function (Renn 1998, 56). As virtually all economists agree that preferences are not homogenous and each individual has its own set of likings, there would also be an infinite number of utility functions (see e.g. Stigler and Becker 1977 to read more on methodological individualism). As Raico $(2012,37)$ writes, the welfare theory that is based on maximized aggregated social utility, has to allow for interpersonal comparisons. Given that welfare theory seems to be more important for the post-war mainstream of neoclassical economists than the utility theory itself, the latter was often subdued under the charm of the first. However, this is again not a monolithic standpoint. Starting from Jevons $(1888,14)$ :

The reader will find that there is never, in a single instance, an attempt made to compare the amount of feeling in one mind with that in another. I see no means by which such comparison can ever be accomplished.

to Arrow $(1963,9)$ :

The viewpoint will be taken here that interpersonal comparison of utilities has no meaning and, in fact, that there is no meaning relevant to welfare comparisons in the measurability of individual utility.

neoclassical welfare analysis has been also based on the assumption that the utilities of different individuals are not comparable. The discussion here is complex and rich, and extracting any homogenous neoclassical approach out of this discussion is not possible, as may be learnt e.g. from Dobb (1973) or Hammond (1991).

\section{Other trouble spots}

For Austrians, the focal point, around which flourishes the economic debate, is an entrepreneur. The concept of utility also concerns entrepreneurship in the largest part. 
Although neoclassical economists undertook a number of attempts to model entrepreneurship (see Bianchi and Henrekson 2005, 17), these frameworks are less flexible than the Austrian one. They might be useful in capturing one specific aspect of entrepreneurship, but fail to account for the complexity and heterogeneity of entrepreneur's profession.

One of the most insightful and conversant critique of the Austrian approach was expressed by Caplan (1999) and then quickly mitigated by Block (1999) and Hülsmann (1999). What this dialogue reveals, and what may be worrying in context of this paper, is that the amalgamation of opposite methodologies may sometimes be unwelcome by scholars themselves. Caplan $(1999,828-829)$ criticizes Rothbard for occasionally referring to neoclassical concepts of income and substitution effects, claiming that, apparently, he thus implicitly admitted the superiority of neoclassical school, since he was unable to develop these insights from within the Austrian tradition. Such a reaction proves that the neoclassical school jealously guards its achievements and is unwilling to share them to benefit from the mixed approach. And as Hülsmann $(1999,11)$ politely replies, there are possibly only "few Austrian economists who would claim that nothing of value could be learned extra muros". In one, however, Caplan may be right. Austrian economists sometimes have tendency to exaggerate the intellectual clash between their school and that of neoclassical flavor, as it was already evidenced in the objectivism vs. subjectivism section.

Interestingly, Austrians, who are normally more flexible, categorically refuse any departure from the diminishing marginal utility, i.e. they oppose the law of increasing marginal utility or constant marginal utility (Mises 1996). Actually, the diminishing marginal utility has been assumed by all three fathers of the marginal utility theory, including Walras and Jevons (Stigler 1950b, 322). However, it is not difficult to imagine the anomaly that contradicts this law, especially with large indivisible goods, like the whole skin of water on the desert, whereas just a cupful of water would do to satisfy one's needs (see Bonar 1888, 10-11). It is somehow strange that Austrian economists, criticizing their neoclassical peers for calling economic events paradoxes, which are only paradoxes under a given framework, are so inflexible with their stance on marginal utility.

It would take (actually, it took) several tomes to replicate complete historical discourse on utility. But referring to the input of also other scholars, and concerning yet other minor hot spots, is not only unfeasible, but would also miss this paper's apple core, which is not to adjudicate past arguments or observe the evolution of the theory, but rather to resolve contemporary misunderstandings. All the references made had thus two major goals: to show when and why the schools split up, and to define and describe key notions associated with 
utility. The methodological discussion is now more limited than in previous decades, and this allows for the comparison of pretty well established utility concepts.

\section{The Resolution}

Even accounting for the heterogeneity apparent within both schools, the must-have properties of utility may be crafted. This paper is not the first attempt to reconcile thinking of utility. For instance, Abdellaoui et al. (Abdellaoui, Barrios, and Wakker 2007) argued, by actually proving it experimentally, that the cardinal utility, mainstream in the 19th century, can successfully be combined with the more contemporary ordinal utility.

Whereas neoclassical economists see value in explicitly maximizing the utility, Austrian economists normally reject both the possibility of impartial determination of utility and of its quantitative representation. However, it still does not wedge the path to agreement, as both factions acknowledge that the human action is inherently egoist and aimed at some form of maximization of pleasure (minimization of pain). Even though Kapteyn $(1985,7)$ implicitly suggests that households may "follow different rules of behaviour" than maximization, and there are occasional voices - like in Herbert Simon's 1978 Nobel lecture that individuals rather "satisfice" than maximize, such indications are typically rejected (Boland 1981, 1031). This philosophical outlook of an individual who takes full advantage of available resources is perhaps the most overlapping element in the teachings of both schools.

However, the serious discrepancy is that the Austrian school does not unequivocally assume strict rationality of an individual. This precondition, at the end of day, would imply that heterogeneous people tend to make quite homogenous choices. Although Mises stated that all social cooperation exemplifies rationally recognized utility, he was later condemned by Hayek for extreme rationalism (Raico 1995, 9 footnote). Nevertheless, human action is purposeful, according to the Austrians, and the economic agent pursues goals she deems right. She also assesses the measures, which lead to fulfillment of these goals, through the prism of utility. Hence, an economic agent planning for herself, although deprived of perfect knowledge, has still the best possible knowledge out of all individuals. Thus, Austrians generally follow neoclassical economics in that humans try to proceed rationally in their actions (Vaughn 1994, 163).

Both schools admit that utility is embodied by everything that individuals value. The difference lies in not what is understood under "everything", but to what extent this everything may be calculated. Even referring to "raw" money, it will carry different utility for 
different individuals. Although only a fraction of neoclassical models deny that different individuals evaluate income differently, the subjective theory of value is still alien to many, e.g. the whole massive genre of representative agent models that uses simplification. Optimistically, the problem gains publicity (An, Chang, and Kim 2009; Kirman 1992) and counter-examples follow (see e.g. Donkers and Soest 1999; Heathcote, Storesletten, and Violante 2009). According to critics of neoclassical modeling, like Huerta de Soto (2008, 107), there is fundamental difference between simplified assumption and unrealistic assumption, and the latter puts neoclassical theoretical inferences in jeopardy. Still, there are economists who just prefer "poor, useful theory" to "a rich, useless one" (Stigler 1950a, 393). Since Milton Friedman's seminal essays (1953), it seems that more value in the mainstream economics is attached to predictive power, as compared with realism of economic theories. Thus, the theories are often validated positively if they happen to predict future correctly, and are despised whenever they fail to foretell accurate GDP growth digits (Hülsmann 1999, 3). This derailment from reason has to be ceased if the close-up between methodologies is at stake. The conviction that accurate predictions may be born from defective model is theoretically harmonious only under the rigor of classical logic, where the conditional statement $\mathrm{p} \rightarrow \mathrm{q}$ is considered true, even if $\mathrm{p}$ is ludicrously false.

With regard to measurability, the door to compromise would remain open if Austrians accept bona fide at least the Paretian (or Walrasian) view of theoretical possibility of utility measurement, which does not necessarily imply that one resorts to quantifying it.

Mathematization is generally viewed as alien to the Austrian economics, although there were trials to incorporate it into the body of this school, made notably by von Neumann \& Morgenstern (1944) and Horwitz (2000). However, the membership of von Neumann and Morgenstern in the current of Austrian school is disputable. McCulloch $(1977,256)$ insists that there are implicit set operations in the Austrian utility analysis, although in the age of "early" Austrians such operations were not considered arithmetic.

It is also worthwhile to spare a note about paradoxes. The term "paradox" does not fit neatly in any scientific field and it is desirable also for economists to steer clear from it. The way to achieve it is through embracing the weak points, which give birth to "paradoxes", by subjectivist standpoint. Virtually, the discussion on paradoxes is the discussion on a degree to which the simplified economic models may abstract from reality. Typically, the Austrian school firmly promotes realism at any price, and the neoclassical school - for the sake of mathematization - went far in simplification efforts. Nevertheless, in the case of marginal utility that may exhibit constant or increasing pattern, the Austrians seem to lack openness. 
For instance, Rajsic (2009) is unconditional in his claims that only the diminishing marginal utility has the right to exist. Although some may call the increasing marginal utility pure and futile theorization, but the obstinate resistance to it is probably not worth the candle.

In essence, main utility-related discrepancies between both schools' teachings, as well as the recommendations aimed at reconciliation, were highlighted in the table below:

Table 2. The possible steps in reconciling Austrian and neoclassical stances on utility

\begin{tabular}{|c|c|c|}
\hline & Austrian & Neoclassical \\
\hline $\begin{array}{l}\text { Unshakable } \\
\text { premises }\end{array}$ & $\begin{array}{l}\text { - Unconditional subjectivity } \\
\text { - Rejection of cardinality of } \\
\text { preferences } \\
\text { - Rejection of advanced } \\
\text { mathematical tools }\end{array}$ & $\begin{array}{l}\text { - Utility as a quantitative concept, } \\
\text { being the basis for other theories } \\
\text { (pragmatic approach) } \\
\text { - Models that simplify the economic } \\
\text { reality and imply objectivity }\end{array}$ \\
\hline Remedies & $\begin{array}{l}\text { - To admit bona fide that utility } \\
\text { might be measured in some } \\
\text { particular instances, based on the } \\
\text { revealed behavior of economic } \\
\text { agents, or the technology } \\
\text { advancement will allow for such } \\
\text { measurements in the future } \\
\text { - To limit the space available for } \\
\text { paradoxes, by incorporating into } \\
\text { the theoretical considerations the } \\
\text { notions of increasing and constant } \\
\text { marginal utility } \\
\text { - To accept basic mathematical } \\
\text { formalism as a supportive tool, } \\
\text { reinforcing theoretical foundations }\end{array}$ & $\begin{array}{l}\text { - To get rid of the deliberate } \\
\text { quantification of utility (including } \\
\text { aggregations and comparisons), } \\
\text { without the underlying reality } \\
\text { check or sanity check } \\
\text { - To espouse on the grounds of } \\
\text { theory that only the subjective } \\
\text { utility credibly expresses the } \\
\text { economic reality, and the objective } \\
\text { concepts used in models are the } \\
\text { description of an idealized world, } \\
\text { of no reference to economic reality } \\
\text { - To weaken the assumption of } \\
\text { rationality when referring to the } \\
\text { motivations of economic agents }\end{array}$ \\
\hline
\end{tabular}

The recommendations featured above are initial steps that may bring the schools closer. This should not be considered a unification of the utility theories, but rather the rapprochement of traditions. It is important to refer to the root of the marginal revolution that freed economists from the idea that the prices of goods are determined by the amount of labor that goes into their production. Both Austrian and neoclassical economists now understand that the prices of goods are determined by their marginal utility, and that the prices of the factors of production are determined by the prices of consumers' goods, so that the entire price nexus rests on utility. This revolution corrected a fundamental flaw in the rationale of classical economists, and the revolution is central to the modern economic way of thinking. 
However, whether this paper will lead to a tangible agreement or not, remains knotty. A good illustration of how unshakable the prevailing dogmas are is given in Hunt and Morgan (1995), who assess the influence of highly mathematized neoclassical economics, with general equilibrium theory and perfect competition in particular, on the discipline of their interest - marketing. "Neoclassical economics has enormous sunk costs in perfect competition (...) Perfect competition is unshakable, immutable, and impregnable. Nothing can be done" (Hunt and Morgan 1995, 13), like ages ago with Ptolemaic astronomy. Ironically, the concept of utility has also survived several attacks, particularly from Samuelson's theory of revealed preference (Kapteyn 1985, 1), aimed to supersede utility. Conversely, a victim of neoclassical school was the Sonnenschein-Mantel-Debreu theorem (nicknamed as "Anything Goes Theorem”), which originated within the neoclassical school in the seventies, but has not been widely accepted since then (Rizvi 2006; Tohmé 2006). Imprecise predictions it gives were the focal point of critique. Apparently, the theorem that says that there might not exist a unique equilibrium point in the economy and that individual demand functions do not sum up perfectly to an aggregate function for the economy, proved too lax to be adopted.

The conciliatory spirit is not the domain of any of the pertinent schools. Whereas the neoclassical scholars, being in majority, may easily ignore the non-mainstream currents, the Austrians more often are tempted to be aggressive. It was quite illustriously depicted in Robert Ekelund's (1997) review of Karen I. Vaughn's (1994) book, which branded the author's stance as "angst-ridden wing of the Austrian movement - those with a penchant for internecine methodological warfare". Simultaneously, Ekelund underlines the Austrianflavored research from many fields that is gradually becoming influential among the mainstream scholars. To name only a few cases, the amalgamation of neoclassical and Austrian strands concerns the new institutional economics (Dequech 2006), economic psychology and information economics (Dickson 1992), as well as the contract law (Wonnell 1986).

\section{Conclusions}

Despite the internal heterogeneity in both schools that was presented throughout the paper, they entrenched themselves in their core views long ago. Nevertheless, this paper shows that discussing utility on common ground and on the basis of shared presumptions is not necessarily the melody of the future. There is a considerable unevenness in this paper as 
regards the depiction of Austrian stances and neoclassical stances, with the Austrian school being slightly more comprehensively elaborated. However, it is for purpose. First, to emphasize to what extent Austrian concepts penetrated through the neoclassical line of thought. Second, to counter the unbalance prevailing in the academic literature, where the notions characteristic for the Austrian tradition are all too often disregarded.

Once the level of internal disagreement may cast doubt on the very existence of coherent schools of economic thinking, thus undermining the whole idea of bringing the two schools together, one should rather focus on the major takeaway of this exercise, which is to show that the concept of utility is firmly rooted in economics, no matter the espoused tradition. Even abstracting from the existence or non-existence of schools sensu stricto, it is vital for the utility to retain its fundamental role in economics teaching. This, clearly, may not happen at the cost of either side giving up ideas that each regards as essential to its research program. Therefore, it is not intended that Austrians should accept the possibility of measurement, aggregates or mathematics, or that neoclassicals should forsake their welfare models.

According to the theory of economic theories, sketched by Stigler (Stigler 1950a, 392396) the sustainable theory should fulfill the criteria of generality, manageability and congruence with reality. Its success is measured "in terms of acceptance by leading economists". The stance of Drakopoulos and Karayiannis $(1999,74-75)$ is that "the utility approach in its early development passed very well the first but had some problems (additive, interpersonal comparisons) with the second and little success with the third" criterion. Further developments made the early marginalism more tolerable and acceptable, but the more assumptions - the less general validity. It seems that the key for marginal utility's success was that its assumptions were uncontroversial, realistic and internally coherent (KurrildKlitgaard 2001, 137-138). What will be the next step?

Many economic wars have passed or antiquated by today, say the freshwater vs. saltwater debate or the Methodenstreit. Similarly, mercantilism and physiocracy, the concepts once prevailing, despite leaving their legacy, all in all have vanished smoothly. It is certainly nowhere close to the incorporation of Austrian wisdom into the mainstream, or the other way round, but the ceasefire on utility may bring both schools closer. Another solution is perhaps, as Colander et al. (2007) suggest, to participate relentlessly in the mainstream conversation, in sheer order to be heard, forgetting one's heterodoxian pride. When all is said and done, as Milton Friedman believed, re-quoted in Caplan (1999, 823), "there is no Austrian economics - only good economics, and bad economics". 


\section{Bibliography}

Abdellaoui, Mohammed, Carolina Barrios, and Peter P. Wakker. 2007. "Reconciling Introspective Utility with Revealed Preference: Experimental Arguments Based on Prospect Theory." Journal of Econometrics 138 (May): 356-378.

Allais, Maurice. 1953. "Le Comportement de L'homme Rationnel Devant Le Risque: Critique Des Postulats et Axiomes de L'école Américaine.” Econometrica 21 (4): 503 546.

An, Sungbae, Yongsung Chang, and Sun-Bin Kim. 2009. "Can a Representative Agent Model Represent a Heterogeneous Agent Economy?" American Economic Journal: Macroeconomics 1 (2): 29-54.

Arnsperger, Christian, and Yanis Varoufakis. 2006. "What Is Neoclassical Economics? The Three Axioms Responsible for Its Theoretical Oeuvre, Practical Irrelevance And, Thus, Discursive Power." Panoeconomicus 1: 5-18.

Arrow, Kenneth Joseph. 1963. Social Choice and Individual Values. 2nd ed. New York, London and Sydney: John Wiley \& Sons, Inc.

Aspromourgos, Tony. 1986. "On the Origins of the Term 'Neoclassical."' Cambridge Journal of Economics 10 (3): 265-270.

Barnett, William. 2003. "The Modern Theory of Consumer Behavior: Ordinal or Cardinal." The Quarterly Journal of Austrian Economics 6 (1): 41-65.

Bentham, Jeremy. 2000. An Introduction to the Principles of Morals and Legislation. Kitchener, ON: Batoche Books.

Benz, Matthias. 2005. "The Relevance of Procedural Utility for Economics". 256. Working Paper Series.

Benz, Matthias, and Alois Stutzer. 2003. "Do Workers Enjoy Procedural Utility?" Applied Economics Quarterly 49: 149-172.

Bianchi, Milo, and Magnus Henrekson. 2005. "Is Neoclassical Economics Still Entrepreneurless?" 584. SSE/EFI Working Paper Series in Economics and Finance.

Blaug, Mark. 2007. "The Fundamental Theorems of Modern Welfare Economics, Historically Contemplated.” History of Political Economy 39 (2): 185-207.

Block, Walter. 1999. "Austrian Theorizing: Recalling the Foundations." The Quarterly Journal of Austrian Economics 2 (4): 21-39.

Böhm-Bawerk, E. v., and Henrietta Leonard. 1891. "The Autrian Economists." Annals of the American Academy of Political and Social Science 1: 361-384. 
Böhm-Bawerk, Eugen von. 1890. Capital and Interest: A Critical History of Economical Theory. London and New York: Macmillan and Co. Ltd.

Boland, Lawrence A. 1981. "On the Futility of Criticizing the Neoclassical Maximization Hypothesis.” The American Economic Review 71 (5): 1031-1036.

Bonar, James. 1888. "The Austrian Economists and Their View of Value." The Quarterly Journal of Economics 3 (1): 1-31.

Bruni, Luigino, and Francesco Guala. 2001. "Vilfredo Pareto and the Epistemological Foundations of Choice Theory" 33 (1): 21-49.

Cannan, Edwin. 1964. A Review of Economic Theory. Cannan, E., A Review of Economic Theory, 2nd Ed., London, 1964. 2nd ed. London.

Caplan, Bryan. 1997. "Why I Am Not an Austrian Economist”. Department of Economics, George Mason University.

1999. "The Austrian Search for Realistic Foundations." Southern Economic Journal 65 (4): 823-838.

Colander, David. 2000. "The Death of Neoclassical Economics." Journal of the History of Economic Thought 22 (2): 127-143.

_ 2007. "Edgeworth's Hedonimeter and the Quest to Measure Utility." Journal of Economic Perspectives 21 (2): 215-225.

Colander, David, Richard P. F. Holt, and J. Barkley Rosser Jr. 2007. "Live and Dead Issues in the Methodology of Economics." Journal of Post Keynesian Economics 30 (2): 303312.

_. 2010. "How to Win Friends and (possibly) Influence Mainstream Economists." Journal of Post Keynesian Economics 32 (3): 397-410. doi:10.2753/PKE01603477320305 .

Cooter, Robert, and Peter Rappoport. 1984. "Were the Ordinalists Wrong About Welfare Economics?” Journal of Economic Literature XXII (June): 507-530.

Daoud, Adel. 2011. "Scarcity, Abundance, and Sufficiency: An Alternative Foundation for Heterodox Economics”. Göteborg: University of Gothenburg, Department of Sociology.

Davenport, Herbert J. 1902. "Proposed Modifications in Austrian Theory and Terminology." The Quarterly Journal of Economics 16 (3): 355-384.

Dequech, David. 2006. "The New Institutional Economics and the Theory of Behaviour under Uncertainty." Journal of Economic Behavior \& Organization 59 (January): 109131. doi:10.1016/j.jebo.2004.03.012.

Dickson, Peter Reid. 1992. "Toward a General Theory of Competitive Rationality.” Journal of Marketing 56: 69-83. 
Diener, Ed, Eunkook M. Suh, Richard E. Lucas, and Heidi L. Smith. 1999. "Subjective WellBeing: Three Decades of Progress." Psychological Bulletin 125 (2): 276-302. http://dipeco.economia.unimib.it/persone/stanca/ec/diener_suh_lucas_smith.pdf.

Dobb, Maurice. 1973. Theories of Value and Distribution since Adam Smith: Ideology and Economic Theory. 1st ed. Cambridge, New York and Melbourne: Cambridge University Press.

Donkers, Bas, and Arthur van Soest. 1999. "Subjective Measures of Household Preferences and Financial Decisions.” Journal of Economic Psychology 20: 613-642.

Drakopoulos, Stavros A., and Anastassios D. Karayiannis. 1999. "Mainstream Consumer Theory: Delay, Acceptance and History of Economic Thought Texts." History of Economics Review (30): 68-81.

Eabrasu, Marian. 2008. “An Assessment of Subjectivism. Its Meaning And Its Limits”. 1. Working Paper Series.

Edgeworth, Francis Ysidro. 1879. "The Hedonical Calculus.” Mind 4: 394-408.

1881. Mathematical Psychics: An Essay on the Application of Mathematics to the Moral Sciences. London: C. Kegan Paul and Co.

Ekelund, Robert B. 1997. "Karen I. Vaughn. Austrian Economics in America: The Migration of Tradition (Book Review).” Review of Austrian Economics 10 (2): 133-138.

Foundation for Research in Economics and Education. 1978. "A Conversation between Friedrich von Hayek, PhD Economics and Axel Leijonhufvud, Professor of Economics, UCLA". United States: The Foundation for Research in Economics and Education. http://www.youtube.com/watch?v=cDNLKMYYArc.

Frey, Bruno S., Matthias Benz, and Alois Stutzer. 2004. "Introducing Procedural Utility: Not Only What but Also How Matters." Journal of Institutional and Theoretical Economics 160 (3): 377-401.

Frey, Bruno S., and Alois Stutzer. 2002. "What Can Economists Learn From Happiness Research.” Journal of Economic Literature 40: 402-435.

2005a. "Beyond Outcomes: Measuring Procedural Utility." Oxford Economic Papers 57 (1): 90-111.

_ 2005b. "Testing Theories of Happiness." In Economics of Happiness. Framing the Analysis, edited by Luigino Bruni and Pierluigi Porta, 116-146. Oxford, UK: Oxford University Press.

Friedman, Milton. 1953. "The Methodology of Positive Economics." In Essays in Positive Economics, 3-43. Chicago: University of Chicago Press.

Gordon, David. 1996. "The Philosophical Origins of Austrian Economics". Auburn, AL. http://mises.org/pdf/philorig.pdf. 
Gül, Faruk, and Wolfgang Pesendorfer. 2006. "Random Expected Utility." Econometrica 74 (1): 121-146.

—. 2013. "Expected Uncertain Utility Theory." Mimeo.

Hammond, Peter J. 1991. "Interpersonal Comparisons of Utility: Why and How They Are and Should Be Made." In Interpersonal Comparisons of Well-Being, edited by Jon Elster and John E. Roemer, 200-254. Cambridge, UK: Cambridge University Press.

Hayek, Friedrich August. 2007. "Carl Menger.” In Principles of Economics, 11-36. Auburn, AL: The Ludwig von Mises Institute.

Heathcote, Jonathan, Kjetil Storesletten, and Giovanni L. Violante. 2009. "Quantitative Macroeconomics with Heterogeneous Households." Annual Review of Economics 1: 319-354.

Hennipman, P. 1987. "A Tale of Two Schools: Comments on a New View of the Ordinalist Revolution.” De Economist 135 (2): 141-162.

Hicks, John Richard. 1946. Value and Capital: An Inquiry into Some Fundamental Principles of Economic Theory. 2nd ed. Oxford, UK: Clarendon Press.

1954. "The Political Element in the Development of Economic Theory by Gunnar Myrdal. Review by John Hicks.” The Economic Journal 64 (256): 793-796.

Hicks, John Richard, and Roy Allen. 1934. "A Reconsideration of the Theory of Value." Economica 1 (1): 52-76.

Hodgson, Geoffrey M. 1998. "On the Evolution of Thorstein Veblen's Evolutionary Economics." Cambridge Journal of Economics 22: 415-431.

Horwitz, Steven. 2000. Microfoundations and Macroeconomics: An Austrian Perspective. London: Routledge.

Huerta de Soto, Jesús. 2008. The Austrian School: Market Order and Entrepreneurial Creativity. Cheltenham, UK and Northampton, MA: Edward Elgar.

Hülsmann, Jörg Guido. 1999. "Economic Science and Neoclassicism.” The Quarterly Journal of Austrian Economics 2 (4): 3-20.

Hunt, Shelby D., and Robert M. Morgan. 1995. "The Comparative Advantage Theory of Competition.” Journal of Marketing 59 (2) (April): 1-15. doi:10.2307/1252069.

Jevons, William Stanley. 1888. The Theory of Political Economy. 3rd ed. London: Macmillan.

Kahneman, D. 1994. "New Challenges to the Rationality Assumption." Journal of Institutional and Theoretical Economics 150: 18-36. 
Kahneman, Daniel. 1999. “Objective Happiness.” In Well-Being: The Foundations of Hedonic Psychology, edited by Daniel Kahneman, Ed Diener, and Norbert Schwarz, 325. New York: Russell Sage Foundation.

Kahneman, Daniel, and Alan B. Krueger. 2006. "Developments in the Measurement of Subjective Well-Being." Journal of Economic Perspectives 20 (1): 3-24.

Kahneman, Daniel, and Amos Tversky. 1979. "Prospect Theory: An Analysis of Decision under Risk." Edited by Daniel Kahneman and Amos Tversky. Econometrica 47 (2): 263-291. doi:10.2307/1914185. http://www.jstor.org/stable/1914185.

Kahneman, Daniel, Peter P. Wakker, and Rakesh Sarin. 1997. "Back to Bentham? Explorations of Experienced Utility." The Quarterly Journal of Economics 112 (2): 375-405.

Kaldor, Nicholas. 1939. "Welfare Propositions of Economics and Interpersonal Comparisons of Utility.” The Economic Journal 49 (195): 549-552.

Kapteyn, Arie. 1985. "Utility and Economics.” De Economist 133 (1) (March): 1-20. doi:10.1007/BF01675959.

Kapteyn, Arie, Bernard M.S. van Praag, and Floor G. van Herwaarden. 1978. "Individual Welfare Functions and Social Reference Spaces.” Economics Letters 1: 173-177.

Kirman, Alan P. 1992. "Whom or What Does the Representative Individual Represent?" The Journal of Economic Perspectives 6 (2): 117-136.

Kirzner, Israel M. 1988. “The Economic Calculation Debate: Lessons for Austrians.” Review of Austrian Economics 2: 1-18.

Kurrild-Klitgaard, Peter. 2001. "On Rationality, Ideal Types and Economics: Alfred Schütz and the Austrian School." The Review of Austrian Economics 14 (2-3): 119-143.

Lange, Oskar. 1934. "The Determinateness of the Utility Function." Review of Economic Studies 1: 218-225.

Langlois, Richard N. 1985. "Knowledge and Rationality in the Austrian School: An Analytical Survey.” Eastern Economic Journal IX (4): 309-330.

Loewenstein, George. 2000. "Emotions in Economic Theory and Economic Behavior." The American Economic Review 90 (2): 426-432.

Mahoney, Dan. 2011. "A Comparison of the Utility Theory of Rothbard and Kirzner." Libertarian Papers 3 (30): 1-19.

Marchionatti, Roberto, and Enrico Gambino. 1997. "Pareto and Political Economy as a Science: Methodological Revolution and Analytical Advances in Economic Theory in the 1890s." Journal of Political Economy 105 (6): 1322-1348.

Marshall, Alfred. 1920. Principles of Economics. 8th ed. London: Macmillan and Co. Ltd. 
Matthaei, Julie. 1984. "Rethinking Scarcity: Neoclassicism, NeoMalthusianism, and NeoMarxism." Review of Radical Political Economics 16 (2/3): 81-94.

McCulloch, J. Huston. 1977. "The Austrian Theory of the Marginal Use and of Ordinal Marginal Utility.” Zeitschrift Für Nationalökonomie 37 (3-4): 249-280.

Meeks, J. Gay Tulip. 1984. "Utility in Economics: A Survey of the Literature.” In Surveying Subjective Phenomena, edited by Charles F. Turner and Elizabeth Martin, Vol. 2, 41-92. New York, NY: Russell Sage Foundation.

Menger, Carl. 2007. Principles of Economics. Auburn, AL: The Ludwig von Mises Institute.

Mill, John Stuart. 1909. Philosophy, Principles of Political Economy with Some of Their Applications to Social Philosophy. Edited by William J. Ashley. 7th ed. London: Longmans, Green and Co.

Mises, Ludwig von. 1996. Human Action: A Treatise on Economics. 4th ed. San Francisco, CA: Fox \& Wilkes.

Morgenstern, Oskar. 1931. "Die Drei Grundtypen Der Theorie Des Subjektiven Wertes." Schriften Des Vereins Für Sozialpolitik 183: 1-42.

Moscati, Ivan. 2013. "How Cardinal Utility Entered Economic Analysis, 1909-1944." The European Journal of the History of Economic Thought 20 (5). CHOPE Working Papers.

Myrdal, Gunnar. 1954. The Political Element in the Development of Economic Theory. Cambridge, UK: Harvard University Press.

Neumann, John von, and Oskar Morgenstern. 1944. Theory of Games and Economic Behavior. 1st ed. Princeton, NJ: Princeton University Press.

Niehans, Jürg. 1989. A History of Economic Theory: Classic Contributions. Baltimore: Johns Hopkins University Press.

O’Driscoll, Gerald P., and Mario J. Rizzo. 1985. The Economics of Time and Ignorance. 1st ed. Oxford and New York: Basil Blackwell Ltd.

Pareto, Vilfredo. 1971. Manual of Political Economy. New York, NY: Augustus M. Kelley.

Phelps Brown, Henry. 1934a. "Demand Functions and Utility Functions." Econometrica, 2: $51-58$.

- 1934b. "Notes on the Determinateness of the Utility Function, I." Review of Economic Studies 2: 66-69.

Pigou, A.C. 1951. "Some Aspects of Welfare Economics." American Economic Review 41: 287-302.

Proops, John L R, and Stefan Speck. 1996. "Comparison of Neoclassical and Neo-Austrian Growth Models.” Structural Change and Economic Dynamics 7: 173-192. 
Raico, Ralph. 1995. "The Austrian School and Classical Liberalism." Advances in Austrian Economics 2A: 3-38.

. 2012. Classical Liberalism and the Austrian School. Auburn, AL: Ludwig von Mises Institute.

Rajsic, Predrag. 2009. "What's Wrong with the Utility Function?” Mises Daily. http://mises.org/daily/3918.

Read, Daniel. 2007. "Experienced Utility: Utility Theory from Jeremy Bentham to Daniel Kahneman." Thinking \& Reasoning 13 (1). Working Paper Series: 45-61.

Renn, Ortwin. 1998. “Three Decades of Risk Research: Accomplishments and New Challenges." Journal of Risk Research 1 (1): 49-71.

Rizvi, S. Abu Turab. 2006. "The Sonnenschein-Mantel-Debreu Results after Thirty Years." History of Political Economy 38 (Suppl. 1) (January 1): 228-245. doi:10.1215/00182702-2005-024.

Robbins, Lionel. 1935. An Essay on the Nature and Significance of Economic Science. 2nd ed. London: Macmillan and Co. Ltd.

Rosenstein-Rodan, Paul. 1960. "Marginal Utility.” International Economic Papers 10: 71106.

Rothbard, Murray N. 1956. "Toward a Reconstruction of Utility and Welfare Economics." In The Freedom and Free Enterprise: The Economics of Free Enterprise. Princeton, NJ: D. Van Nostrand.

- 1962. Man, Economy, and State. Los Angeles, CA: Nash Publishing.

-1995. Classical Economics. Auburn, AL: Edward Elgar.

- 1997. "Praxeology: The Methodology of Austrian Economics." In The Logic of Action One: Method, Money, and the Austrian School, 77:58-77. Cheltenham, UK: Edward Elgar.

Salerno, Joseph T. 2002. "The Rebirth of Austrian Economics - In Light of Austrian Economics.” The Quarterly Journal of Austrian Economics 5 (4): 111-128.

Samuelson, Paul A. 1937. "A Note on Measurement of Utility." The Review of Economic Studies 4 (2): 155-161.

- 1938. "A Note on the Pure Theory of Consumer's Behaviour." Economica 5 (17): $61-71$.

1948. "Consumption Theory in Terms of Revealed Preference." Economica 15 (60): $243-253$. 

385.

1950. "The Problem of Integrability in Utility Theory." Economica 17 (68): 355-

Seligman, Edwin R.A. 1903. "On Some Neglected British Economists, 1.” The Economic Journal 13 (51): 335-363.

Sen, Amartya K. 1985. Collective Choice and Social Welfare. San Francisco, CA: HoldenDay.

Senior, Nassau William. 1836. An Outline of the Science of Political Economy. $1965 \mathrm{rpt}$. New York, NY: Augustus M. Kelley.

Setterfield, Mark. 2009. "Neoclassical Growth Theory and Heterodox Growth Theory:

Opportunities For and Obstacles To Greater Engagement”. 0901. Working Paper Series.

Sidrauski, Miguel. 1967. "Rational Choice and Patterns of Growth in a Monetary Economy." The American Economic Review 57 (2): 534-544.

Stigler, George J. 1950a. "The Development of Utility Theory. II." The Journal of Political Economy 58 (5): 373-396.

Stigler, George J. 1950b. “The Development of Utility Theory. I." The Journal of Political Economy 58 (4): 307-327.

Stigler, George J., and Gary S. Becker. 1977. "De Gustibus Non Est Disputandum.” The American Economic Review 67 (2): 76-90.

Stringham, Edward Peter. 2010. "Economic Value and Costs Are Subjective." In Handbook of Contemporary Austrian Economics, edited by Pieter J. Boettke, 43-66. Cheltenham, UK and Northampton, MA: Edward Elgar.

Sweezy, Alan. 1934. "The Interpretation of Subjective Value Theory in the Writings of the Austrian Economists." Review of Economic Studies 1: 176-185.

Tarascio, Vincent J. 1969. "Paretian Welfare Theory: Some Neglected Aspects." Journal of Political Economy 77 (1): 1-20.

Tinbergen, J. 1991. "On the Measurement of Welfare.” Journal of Econometrics 50: 7-13.

Tohmé, Fernando. 2006. "Rolf Mantel and the Computability of General Equilibria: On the Origins of the Sonnenschein-Mantel-Debreu Theorem." History of Political Economy 38 (Suppl. 1) (January 1): 213-227. doi:10.1215/00182702-2005-023.

Tversky, Amos, and Daniel Kahneman. 1992. "Advances in Prospect Theory: Cumulative Representation of Uncertainty." Journal of Risk and Uncertainty 5 (4): 297-323. doi:10.1007/BF00122574.

Vaughn, Karen I. 1994. Austrian Economics in America: The Migration of a Tradition. Cambridge, New York and Melbourne: Cambridge University Press. 
Veblen, Thorstein. 1898. "Why Is Economics Not an Evolutionary Science?" Quarterly Journal of Economics 12 (4): 373-397.

Vernengo, Matías. 2010. "Conversation or Monologue? On Advising Heterodox Economists.” Journal of Post Keynesian Economics 32 (3): 389-396.

Walras, Léon. 1954. Elements of Pure Economics, or the Theory of Social Wealth. London: Allen \& Unwin.

White, Lawrence. 2003. "The Methodology of the Austrian School Economists". New York, NY: The Ludwig von Mises Institute.

Wonnell, Christopher T. 1986. "Contract Law and the Austrian School of Economics." Fordham Law Review 54 (4): 507-543. 